\title{
Upaya Mengembangkan Motorik Kasar Anak Usia 5-6 Tahun Melalui Permainan Bola Basket (Modifikasi) Di TK Putik Harapan Kecamatan Percut Sei Tuan Kabupaten Deli Serdang
}

Received: 10 Februari $2020 \quad$ Revised : 15 April 2020

Accepted : 2 Juni 2020

\author{
Devi Muliana Sari ${ }^{1}$, Sariana Marbun ${ }^{2}$ \\ Fakultas Ilmu Pendidikan \\ Universitas Negeri Medan \\ Jln. Willem Iskandar Psr V Medan Estate
}

E-mail : devimulianasari@gmail.com

\begin{abstract}
Abstrak. Rumusan masalah dalam penelitian ini adalah: "Apakah dengan melalui permainan bola basket (modifikasi) dapat mengembangkan motorik kasar anak usia 5-6 tahun di TK Putik Harapan". Tujuan dari penelitian ini adalah untuk mengembangkan motorik kasar anak usia 5-6 tahun di TK Putik Harapan.

Jenis penelitian yang digunakan penulis adalah penelitian tindakan kelas (PTK) dan terdiri dari 2 siklus dimana setiap siklus terdiri dari empat komponen yaitu: perencanaan, tindakan, observasi dan refleksi. Subjek penelitian adalah anak kelas B yang berjumlah 20 orang. Alat pengumpul data yang digunakan penulis adalah lembar observasi. Teknik Analisis data menggunakan rumus $\mathrm{Pi}=\mathrm{f} / \mathrm{n} \times 100 \%$.

Hasil analisis siklus I diperoleh data bahwa sebanyak 10 orang (50\%) anak yang tergolong cukup aspek pengembangan motorik anak, 10 orang (50\%) anak yang tergolong baik perkembangan motorik anak. Dari data hasil observaasi tersebut sehingga perlui dilakukan pembelajaran melalui metode permainan modifikasi bola basket yang lebih baik pada siklus 2. Dari hasil analisis siklus 2 diperoleh hasil bahwa kemampuan motorik kasar anak meningkat yaitu bahwa jumlah anak yang kemampuan motorik kasar anak tergolong sangat baik motorik kasar anak bertambah menjadi 18 orang (1844.34\%), anak yang tergolong baik menjadi 2 orang (155.54\%).
\end{abstract}

Dari hasil penelitian dapat disimpulkan bahwa permainan bola basket (modifikasi) dapat mengembangkan kemampuan motorik kasar anak usia 5-6 tahun di TK Putik Harapan Kecamatan Percut Sei Tuan Kabupaten Deli Serdang Tahun Ajaran 2016/2017.

Kata Kunci: Bola Basket, Motorik Kasar

\section{PENDAHULUAN}

Danar Santi : 2009 menyatakan pendidikan anak usia dini adalah pendekatan pedagogis dalam penyelenggaraan pendidikan yang menitik beratkan pada peletakan dasar ke arah pertumbuhan dan perkembangan fisik (koordinasi motorik halus dan kasar), kecerdasan (daya oikir, daya cipta, kecerdasan emosi, kecserdesan spritual), sosial emosional (sikap dan perilaku serta agama) bahasa dan komunikasi, sesuai dengan keunikan dan tahaptahap perkembangan yang dilalui oleh anak usia dini.

Menciptakan suasana yang kondusif dan nyaman untuk anak agar tidak merasa bosan dan ngantuk pada saat proses kegiatan pembelajaran sedang berlangsung. Pendidik 
seharusnya memberikan kebebasan pada anak untuk kegiatan bermain. Pada saat bermain dapat terlihat perkembangan anak yang telah dicapai dilingkungannya. Selain itu, bermain dapat mengembangkan aspek perkembangan anak usia dini.

Salah satu aspek yang harus dikembangkan pada anak usia ini adalah aspek perkembangan fisik motorik yang membutuhkan keseimbangan dan koordinasi antar anggota tubuh dengan menggunakan otot-otot besar sebagian atau keseluruhan anggota tubuh. Menurut Eva Noorlaila (2010) mengatakan perkembangan motori anak akan lebih teroptimalkan jika lingkungan tempat tumbuh kembang anak mendukung mereka untuk bergerak bebas. Perubahan perkembangan yang positif sangat diharapkan sudah dapat diarahkan sedini mungkin, sejak anak dengan cara memberikan kesempatan bergerak banyak, menempatkan pola gerak yang benar dengan pendekatan multilateral, bermain dengan dunianya, sehingga terciptanya perubahan terhadap kebugaran fisik anak.

Berdasarkan pengamatan yang dilakukan oleh guru di TK Putik Harapan, ternyata perkembangan fisik motorik kasar anak belum berkembang sesuai dengan tahapan usianya. Hal ini ditandai dengan munculnya 10 dari 20 orang anak di kelas B kurang bergerak, dalam kegiatan anak-anak cenderung terlalu banyak melakukan aktifitas yang sukai oleh anak sehingga dapat membahayakan diri anak itu sendiri. Pada saat pemberian tugas anak kurang mampu menyelesaikan tugasnya sampai selesai, dari 20 orang anak hanya 10 orang anak yang mampu mengikuti gerakan berlari dan mengikuti gerakan seperti daun melambai-lambai yang disuruh namun tidak sampai selesai dan sempurna.

\section{METODOLOGI PENELITIAN}

Metode penelitian yang digunakan dalam penelitian ini adalah jenis PTK (Penelitian Tindakan Kelas). PTK adalah penelitian yang dilakukan oleh guru dikelasnya sendiri melalui refleksi diri dengan tujuan umtuk memperbaiki kinerjanya sehingga hasil belajar anak meningkat. Arikunto (2012:16) menyatakan "Penelitian Tindakan Kelas (PTK) adalah suatu pencermatan terhadap kegiatan belajar berupa tindakan dengan pendekatan kolaborasi yang sengaja dimunculkan dan terjadi dalam sebuah kelas secara bersaman. Tindakan tersebut diberikan oleh guru atau dengan arahan dari guru yang dilakukan oleh anak didik. Penelitian ini bertujuan untuk menyelesaikan permasalahan pengembangan motorik kasar anak usia 5-6 tahun melalui permainan modifikasi (bola basket) agar anak berkembang sesuai dengan harapan. Dari definisi diatas, maka populasi dalam penelitian ini adalah seluruh anak di di TK Putik Harapan yang berjumlah 20 anak yang terdiri dari 12 (dua belas) anak perempuan dan 8 (delapan) anak laki-laki pada tahun ajaran 2016/2017.

Dalam penelitian ini teknik pengumpulan data yang digunakan adalah observasi. Metode observasi dilakukan dengan cara mengamati dan mencatat semua aktivitas anak pada proses kegiatan kolase di kelas. Observasi dilakukan pada anakkelompok Buntuk memperoleh data anak yang berkaitan dengan aspek-aspek kreativitas anak.Penyusunan data dilakukan dengan memuat namaanak.Tugas observer memberi tanda checklist $(\checkmark)$ pada skor yang di dapat melalui pedoman observasi yang dibuat. Dari observasi yang dilakukan maka diperoleh data perkembangan kamampuan motorik kasar anak. 
Tabel 1 Kisi-kisi Pengembangan Motorik Kasar

\begin{tabular}{|c|c|c|c|}
\hline Variabel & $\begin{array}{c}\text { Aspek } \\
\text { Perkembangan } \\
\text { Anak }\end{array}$ & Indikator & Deskriptor \\
\hline \multirow[t]{6}{*}{$\begin{array}{l}\text { Perkemba- } \\
\text { ngan } \\
\text { Motorik } \\
\text { Kasar }\end{array}$} & \multirow[t]{4}{*}{$\begin{array}{l}\text { Lokomotor dan } \\
\text { Nonlokomotor }\end{array}$} & Berjalan & $\begin{array}{l}\text { 1. Berjalan dengan menaikkan dan } \\
\text { menurunkan badan. } \\
\text { 2. Berjalan berpasangan dengan } \\
\text { memegang bahu temannya. } \\
\text { 3. Berjalan mengikuti pola suatu } \\
\text { garis. }\end{array}$ \\
\hline & & Lari & $\begin{array}{l}\text { 1. Berlari sambil membawa bola. } \\
\text { 2. Berlari dengan cepat. } \\
\text { 3. Berlari dan mempertemukan } \\
\text { telapak tangan dengan } \\
\text { temannya. }\end{array}$ \\
\hline & & $\begin{array}{l}\text { Meloncat dan } \\
\text { melompat }\end{array}$ & $\begin{array}{l}\text { 1. Melompat kedalam kotak dan } \\
\text { lingkaran. } \\
\text { 2. Meloncat dengan seimbang } \\
\text { tanpa jatuh. } \\
\text { 3. Meloncat dari ketinggian } 30-50 \\
\mathrm{~cm} \text {. }\end{array}$ \\
\hline & & Nonlokomotor & $\begin{array}{l}\text { 1. Meliukkan anggota badan } \\
\text { 2. Mengayunkan tangan } \\
\text { 3. Membungkukkan badan }\end{array}$ \\
\hline & \multirow[t]{2}{*}{ Manipulatif } & Melempar & $\begin{array}{l}\text { 1. Melempar bola dengan diam di } \\
\text { tempat. } \\
\text { 2. Melempar bola dari atas kepala } \\
\text { 3. Melempar bola dari bawah }\end{array}$ \\
\hline & & Menangkap & $\begin{array}{l}\text { 1. Menangkap bola dengan kedua } \\
\text { tangan. } \\
\text { 2. Menangkap bola dari } \\
\text { lambungan teman } \\
\text { 3. Menangkap bola dari atas } \\
\text { kepala }\end{array}$ \\
\hline
\end{tabular}

Keterangan :

Kriteria 3 atau Baik (B) : jika 3 deskriptor tampak pada anak

Kriteria 2 atau Cukup (C) : jika 2 deskriptor tampak pada anak

Kriteria 1 atau Kurang (K) : jika 1 deskriptor tampak pada anak

Kriteria 0 atau Sangat Kurang : jika tidak satu pun deskriptor tampak

\section{HASIL DAN DISKUSI}

Telah diterangkan sebelumnya pada bab III bahwa dalam penelitian ini dikumpulkan dengan teknik observasi. Lembar observasi telah disusun sehingga dapat digunakan untuk melihat data perkembangan kreativitas anak. 
Dari observasi, dapat dilihat bahwa dengan kegiatan membatik memberikan perbedaan pada perkembangan kreativitas anak di kelas kontrol dan kelas eksperimen. Perbedaan tersebut dapat dilihat dalam tabel dibawah ini

Tabel 2. Rekapitulasi Persentase Kemampuan Motorik Kasar Anak Pada Siklus I dan Siklus II

\begin{tabular}{ccc}
\hline Keterangan & Siklus I & Siklus II \\
\hline Rata-rata & $61.10 \%$ & $92.21 \%$ \\
\hline
\end{tabular}

Dari tabel diatas dapat terlihat adanya peningkatan kemampuan motorik kasar anak mulai dari siklus I pertemuan II nilai rata-rata anak $61,10 \%$, kriteria baik dan siklus II pertemuan II nilai rata-rata anak $92,21 \%$ kriteria sangat baik

\section{PEMBAHASAN}

Dari analisis data yang dilakukan pada siklus I pertemuan II, nilai rata-rata anak $61,10 \%$ termasuk kategori baik. Dari 20 orang anak yang diobservasi anak (100\%) kemampuan motorik kasar cukup Dari hasil tindakan yang dilakukan pada siklus II pertemuan II dari 20 orang anak, nilai rata-rata yang diperoleh adalah $(92,21 \%)$ termasuk dalam kategori sangat baik. Terdapat sebanyak 2 orang anak $(155,54 \%)$ kemampuan motorik kasar anak baik. Dan 12 orang anak $(1844,34 \%)$ berkembang dengan sangat baik. Dalam siklus II sudah tidak ditemukan lagi anak yang perkembangan kemampuan motorik kasar dalam kategori baik. Terjadi pengingkatan kemampuan motorik kasar anak dengan nilai rata-rata anak $61,10 \%$ pada siklus I menjadi $.92,21 \%$ pada siklus II.

Pada siklus II ini penelitian dilakukan dengan memperbaiki kesulitan-kesulitan yang dihadapi anak untuk memperoleh perkembangan kemampuan motorik anak yang maksimal. Penerapan solusi-solusi pada siklus ini, memberi dampak yang positif pada anak. Saat kegiatan berlangsung terlihat anak lebih bersemangat dalam melakukan kegiatan permainan bola basket.

Pada siklus II terjadi perkembangan kemampuan motorik kasar yang signifikan yaitu sebesar 92,21\%. Perkembangan kemampuan motorik kasar anak yang menunjukkan bahwa permainan bola basket efektif digunakan untuk mengembangkan kemampuan motorik kasar anak. Dengan menggunakan bola basket anak menjadi lebih mudah untuk mengembangkan kemampuan motorik kasar. Dalam proses pembelajaran anak dituntut untuk berfikir dan bergerak.

Kemampuan motorik sangat penting untuk dikembangkan terutama kemampuan motorik kasar. Mengembangkan kemampuan anak dalam bergerak/ aktifitas dapat meningkatkan kemampuan aktifitas anak, sehingga anak memiliki fondasi untuk mampu bergerak dengan ruang lingkup yang baik untuk anak. Oleh karena itu dalam melakukan gerakan bagi anak, tidak hanya menggunakan bola atau media gambar tetapi harus diiringi dengan melakukan aktifitas olahraga dengan iringan musik. Salah satunya dengan menggunakan modifikasi permainan bola basket.

Menurut Husdarta (Dalam Lutan 2011:179) bahwa dengan memodifikasi permainan bola basket dapat tersampaikan dan disajikan dengan tahap-tahap perkembangan motorik anak 
agar memperoleh kepuasan pada saat bermain dan belajar, serta melakukan pola gerak secara beraturan. Sehingga dapat merangsang berbagai aspek yang ada pada diri anak.

Dengan demikian maka hipotesis tindakan dalam penelitian ini dapat terjawab bahwa melalui permainan bola basket (modifikasi) dapat mengembangkan motorik kasar anak usia 5-6 tahun di TK Putik Harapan.

\section{SIMPULAN}

Berdasarkan hasil penelitian dan pengolahan data pada sub bab sebelumnya dapat di ambil kesimpulan, yaitu : kemampuan motorik pada anak kelompok B di TK Putik Harapan dapat mengembang dengan sangat baik melalui permaianan bola basket (modifikasi). Hal ini ditunjukkan dengan hasil yang dicapai pada tindakan Siklus I sebanyak 10 orang $(50 \%)$ anak yang tergolong cukup, 10 orang $(50 \%)$ anak yang tergolong. Baik .Pada tindakan Siklus II sebanyak .18 orang anak (90\%) anak yang tergolong .sangat baik . dan 2 orang (10\%) anak yang tergolong baikPerkembangan kreativitas anak dikelas eksperimen yang dikembangkan melalui kegiatan kolase dengan ampas kelapa berwarna lebih baik dibandingkan perkembangan kreativitas anak dikelas kontrol yaitu menempel gambar pola.

Berdasarkan kesimpulan diatas, maka peneliti mengajukan beberapa saran yaitu :

1. Hendaknya guru menggunakan metode permainan bola basket yang bervariasi agar kemampuan motorik kasar anak tentang melakukan gerakan lokomotor, nonlokomotor dan manipulatif dapat meningkat secara maksimal.

2. Bagi pihak sekolah TK Putik Harapan menyediakan bola untuk pengembangan kemamampuan motorik kasar tentang melakukan gerakan lokomotor, nonlokomotor dan manipulatif dengan mengikut sertakan guru unutk mengkuti pelatihan-pelatihan akan pembuatan media yang diperlukan dalam proses pembelajaran yang mampu mengembangkan kemampuan motorik kasar anak.

3. Bagi peneliti menjadi masukan untuk menyadari akan pentingnya penggunaan media yang bervariasi untuk anak dalam proses pembelajaran, terutama dalam pengembangan motorik kasar anak.

4. Bagi peserta didik hendaknya lebih aktif, percaya pada kemampuan sendiri serta lebih bersemangat dalam belajar terutama dalam pelajaran motorik kasar agar hasil belajar menjadi lebih baik.

5. Bagi peneliti lain dapat melanjutkan penelitian lain yang sejenis atau yang berhubungan.

\section{DAFTAR RUJUKAN}

Arikunto, Suharsimi . 2010 . Prosedur Penelitian .Jakarta : Rineka Cipta

Agus, Dariyo. 2011. Psikologi Perkembangan Anak 3 Tahun Pertama.Bandung : Refika Aditama

Deputi , Asisten Olaharaga Khusus Deputi Bidang Pembudayaan Olahraga Kementrian Pemuda dan Olahraga . 2013. Jakarta

Desmita . 2008. Psikologi Perkembangan . Bandung : Remaja Rosda Karya

Dewi , Rosmala. 2010. Profesionalisasi Guru Melakukan Penelitian Tindakan Kelas. Medan. Pasca Sarjana Unimed .

Hurlock Elizabeth B. 1987.Perkembangan Anak Jilid I.Jakarta: Erlangga 
Jurnal , selasa/22/032016-13.00. Gustiana Asep Deni.2011. Pengaruh Permainan Modiifkasi terhadap Kemampuan Motorik Kasar dan Kognitif Anak Usia Dini (Studi Kuais Eksperimen Pada Kelompok B Tk Kartika dan Tk Lab \UPI).Bandung Noorlaila Iva . 2010. Panduan Lengkap Mengajar PAUD. Yogyakarta : Pinus

Rudyanto dan Yudha.(2005) . Pembelajaran Kooreratif Untuk Meningkatkan Keterampilan Anak TK.Jakarta : Departemen Pendidikan Nasional

Santi , Danar. 2009. Pendidikan Anak Usia Dini. Jakarta : Indeks

Sujiono ,Bambang dkk . (2010). Metode Pengembangan Fisik.. Jakarta : Universitas Terbuka.

Sujiono,Yuliani Murani dan Bambang Sujiono.2012 . Bermain Kreatif Beerbasis Kecerdasan Jamak. Jakarta : Indeks

Sumantri. (2005). Model Pengembangan Keterampilam Motori Kasar Anak Usia Dini .Jakarta : Departeman Pendidikan Nasional

Suharta Asep.2007.Pendekatan Pembelajaran Bola Voli Mini Sebuah Gagasan Konseptual.Bandung: Jurnal Iptek Olahraga UPI

http//:bidanku.com/perkembangan-motorik-kasaranak\#ixzz2q6chTrv.

http//: mainbasket.wordpress.html (Toto Sudarsono2011)

http//:pojokpenjas.com.2008/12/mmodifikasi-pembelajarapendidikan.html 